\title{
The Alföld: Denomination and Its Southern Boundary
}

\author{
T. Gaudenyi and M. Mihajlović
}

\section{ABSTRACT}

\begin{abstract}
The Alföld with its central position in the Carpathian Basin and eastern position in the Pannonian Plain represents the landscape or physicogeographical unit of Carpathian-Pannonian region.
\end{abstract}

Following the recommendation of the Hungarian Geographical Society's Alföld Commission (from 1910) the Alföld should use as a geographic name and the previous denomination "Great Hungarian Plain" should be abandoned. Some parts/segments of the Alföld if use in the context restricted to the national boundaries, the proposed recommendation should be the form of the Alföld with the prefix which according to the country which taking a part of the pointed segment (i.e., in case of Serbia it should mention: Serbian segment of the Alföld).

The southern boundary of the Alföld is well defined. It is same as SE part of the Pannonian Plain. The south parts of the Alföld encompass the Lower Sava Plain (Donja Posavina), the Tamnava-Kolubara plain, the Velika Morava Plain (Pomoravlje) and the Mlava Plain.

Keywords: Alföld; Great Hungarian Plain; Carpathian Basin; geomorphologic subdivision; landscape.

\section{INTRODUCTION}

In the general context the term Alföld (in Serbian: Alfeld) used as landscape unit and a physico-geographical unit however the name was also in the use as administrative unit of Hungary. Moreover, the organized geographical investigations of the Alföld started more than century ago, but the WWI and the later political and scientific community left the results and the objectives ad acta. The recent published atlases keeping the term Alföld in their terminology (e.g., Kocsis \& Schweizer [1], Kocsis, [2]), however in the monographs and textbooks still used for the same area and context the geographical name "Great Hungarian Plain" (e.g., Lóczy [3], Mezősi [4]).

The aim of this paper is to elaborate ideas and investigations of Cholnoky [5] with critical analysis, in purpose to find a logical recommendation which term should be the most appropriate for the denomination (the Alföld or the Great Hungarian Plain) and to define (as well as delineate) its area using geomorphological methods and geologic data. Moreover, we attempt to make an arbitrary decision of the denomination on international level.

\section{MATERIAL AND METHODS}

The total the area which we analyzed was based on the DEM-s of $30 \mathrm{~m}$ resolution. They were used from the Earth Explorer DEM collection of the United States Geological Survey (https://earthexplorer.usgs.gov). It has been merged using the QGIS software. The pixel resolution used in our case was $100 \times 100 \mathrm{~m}$. The total number of 78 DEM-s which were merged in one single DEM.
The study beside the geologic surveying data for the study, on the DEM the roughness tool of QGIS Software used for the delineation same as it was used for the Sava Plain [6], Pannonian Plain [7] and the Carpathian Basin [8].

Roughness QGIS should be described briefly as: "Tools to analyze and visualize DEMs outputs the single-band raster with values computed from the elevation. Roughness is the degree of irregularity of the surface. It is calculated by the largest inter-cell difference of a central pixel and it is surrounding cell. The determination of the roughness plays role in the analysis of terrain elevation data. It is useful for calculation of river morphology and physical geography in general, is derived from the GDAL DEM utility" [9].

The DEM resolution $100 \times 100 \mathrm{~m}$ was chosen which results for the generalizing surficial image gives similar values as other analysis. With the tool "Roughness" of QGIS software we separate the surface roughness in five classes. The plain terrain of the Alföld was defined with roughness coefficients of 0-5 which was analyzed for the whole area of the middle part of the Carpathian Basin testing same criteria of relief elements. Later the generalization and the delineation were drawn manually.

The southern boundary of the Alföld of its definition take in account the major seminal works of Cholnoky [5], [10][12], Bulla [13], [14], Pécsi [15], as well as the recently published review chapters i.e., Dövényi [16], Lóczy et al. [17], Lóczy [3], Mezősi [4] and new recently published investigations (e.g., Kocsis [2]). 


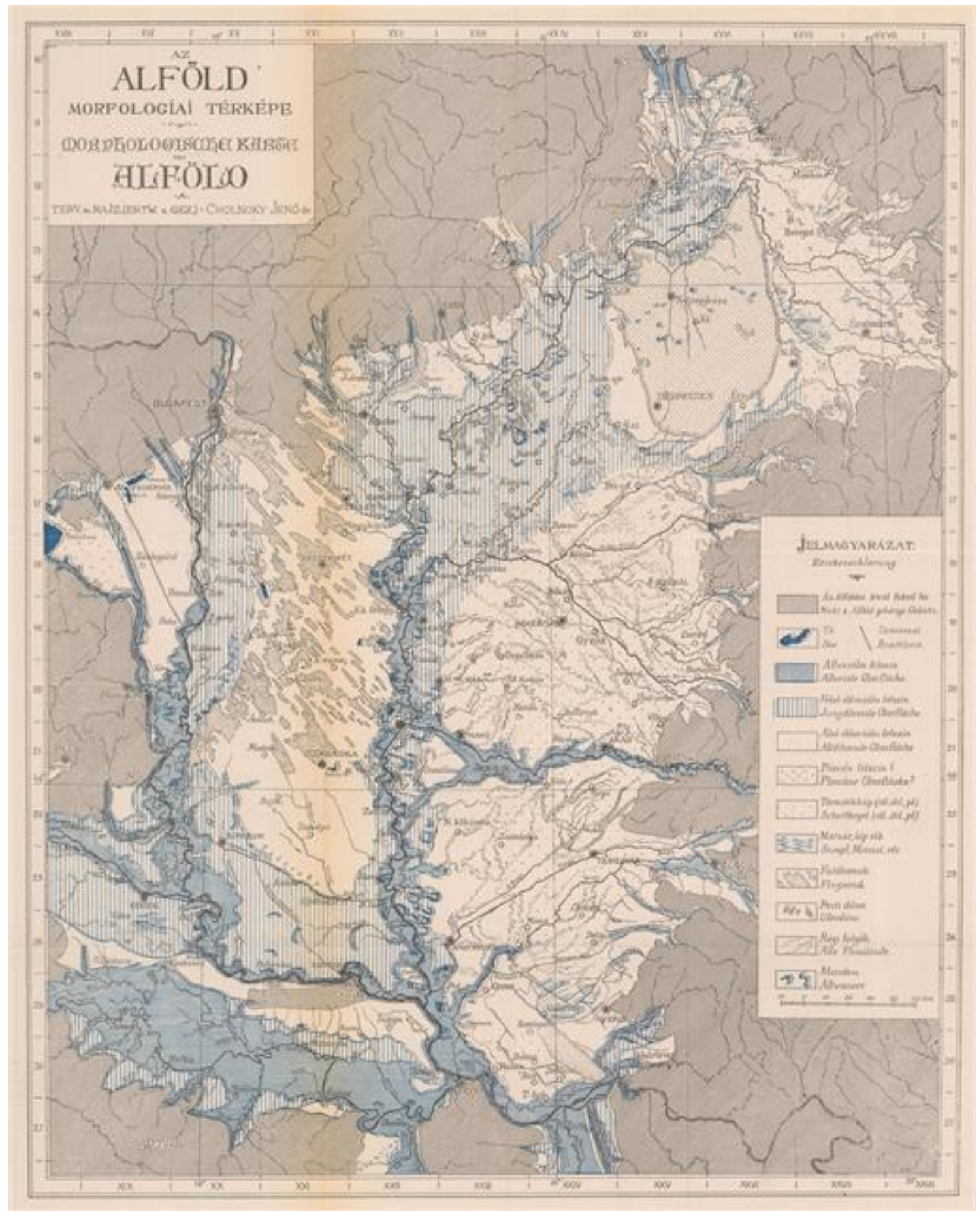

Fig. 1. Morphological map of the Alföld complied by Cholnoky [5] (cropped from [5] p. 497).

\section{RESULTS}

\section{A. The History of the Denomination of the Alföld}

The Hungarian became an official language in Hungarian part of the Austrian Empire in 1844. The term Alföld immediately became in the use, even in the scientific literature the term Alföld often used (e.g., Szabó [18], Hunfalvy [19], Hanusz [20], Czirbus [21]).

"The first systematic research into the physical geography of a region in a true Humboldtian conception, was conducted by a populous group of scientists in the Lake Balaton Basin under the guidance of L. Lóczy Sen. (1849-1920), the most eminent figure in Hungarian geology and geography" ([7] p. 206). The organized as well as systematic geographical investigations of the Alföld began with the coordination of the Hungarian Geographical Society. The Lake Balaton Commission on Nov. $12^{\text {th }}, 1908$, converted to the Alföld Commission of Hungarian Geographical Society (hereinafter: the Alföld Commission). The Alföld Commission headed by Lóczy's former student J. Cholnoky (1970-1950) and it was more-less active till the end of 20-ies 
of $20^{\text {th }}$ century. The end of activities of the Alföld Commission is closely related to its Head and the political situation (the move of university employees which after the WWI were outside of the Hungarian border and it affects personally Cholnoky also). However, Cholnoky's other activities became of higher priority, he also mentioned that it has not a such importance to continue the acietific activitiies of the Alföld Commission because the southern and eastern parts of the Alföld lost Hungary in the WWI (sensu Fodor, [22]). Last but not at least the lack of finances for sciences or changes the priorities of scientific investigations.

In one of the five most important papers of Cholnoky (sensu Fodor [22]) was that in which the denomination of the Alföld, and its application of its geographical name in the international correspondence is clarified ( $c f$. Cholnoky [5]). The accepted proposal was that the Great Hungarian Plain / Great Plain / Hungarian Plain have to be abandoned and it use in the international literature is not justified. The one of the main conclusions of Cholnoky's paper [5]) geographical name Alföld must exclusively use in the national and international correspondence.

The previously used Great Plain (in Hungarian: NagyAlföld / Nagyalföld) is not appropriate because it associates to the Great Plains of North America. The Great Hungarian Plain as Cholnoky [7] justified the geographical name is confused because its edge is outside of Hungary. Later with the changes of boundaries of Hungary after WWI it became more evident. The Alföld (in Hungarian it means lowland or plain) clearly pointed the geographic region / landscape in the central part of the Carpathian Basin (in between Little Alföld and the Transylvanian Basin). Cholnoky [5] when in French used the Alföld Commission name proposed the form "Commission de l'Alföld". It justified that was created on similar way when other geographic names have roots from appellative names in such case as the Alps, Niagara, Balaton.

\section{B. The southern boundary of the Alföld}

This study's starting point in the case of delineation was paper of Cholnoky [5] and his map (Fig. 1). The mentioned paper without map was published again in 1924 in two separated parts [11] [12]. The morphological map of the Alföld from 1910 [5] shows quite clear its main parts except the south-westen and the southern segments (Fig. 1). In the paper of Cholnoky ([5] p. 421) mentioned that the "Nunc venio ad fortissimum. The Alföld continues in the Drava and the Sava valley..." In case of the Sava Valley stated: “...It seems that we can delineate its SW boundary of the Alföld at Slavonski- and Bosanski Brod where the Sava valley became narrower". Moreover, for the Drava written the following"... The Drava plain continues as a wide openness to the Szigetvár area towards in the direction of Pécs, and the Railway Station of Pécs is still in the Alföld." "It should be a matter of compromise to which area of the Drava plain encompass the Alföld. The opinion is that Osijek, Siklós, and Szigetvár should be parts of the Alföld nearly to Barcs".

The studies of Bulla [13], [14] pointed clearly that the Drava Plain from Barcs and eastwards belongs to the Alföld. In case of Sava Plain from Slavonski- and Bosanski Brod eastwards (Lower Sava Plain sensu Gaudenyi \& Mihajlović, [6]) the plain area encompasses the Alföld.
Pécsi [15] only focuses and analyzed the Hungarian segment of the Alföld (in his study used the term "Great Hungarian Plain" and stated that the Drava floodplain belongs to the Alföld.

The recent regional/review studies Lóczy [3] [17], Mezősi [4] following/adopted the "Great Hungarian Plain" concept and according to the conclusions of Pécsi [15]. In most cases only mentioned that more than a half of the area of Alföld is in Hungary, while in their articles only the area of Hungary evaluated.

The used the geographical name Alföld in the chapter of Schweizer [1] were correctly mentioned that $100,000 \mathrm{~km}^{2}$ of the Alföld $52,000 \mathrm{~km}^{2}$ are in the territory of Hungary.

The results of the roughness analysis shown on the Fig. 2. The area with 0-5 roughness coefficients was considered that the almost flat lowland relief shown. The area of the Alföld also presented on the topographical environments.

The new studies and analysis of Telbisz in Gábris et al. [23] based on digital terrain models represents a set of useful maps and promoted the relief visualization on excellent way: the slope category map of the Carpathian-Balkan Region (Map 5 in [23]); the map for the relative relief of the CarpathianBalkan Region (Map 6 in [23]); and the map of terrain types of the Carpathian-Balkan Region (Map 7 in [23]). The landscape subdivision the historical landscape types in the Carpathian Basin from $11^{\text {th }}$ till the $16^{\text {th }}$ century (Map 2 in Csorba et al. [24]) Taxonomy of the natural landscapes (Map 19 for the Carpathian Basin and Map 22 for Hungary in [24]). The results of this study obtain with the surface roughness classes are very similar to those in Kocsis [2] also it is compatible with the previous studies of in case of the Serbian segment of the Alföld as defined after Ćalic et al. [25], [26].

\section{DISCUSSION}

Despite the German language influence and many primary Hungarian geographers preferred the term Great Hungarian Plain in English or the authors just translate from the German Grosse Ungarische Tiefebene (e.g., Trunkó [27]) or in earlier references as Grosse Ungarische Ebene (e.g., von Raumer, [28]) or niederungarische Ebene (e.g., Wolf [29]) to English, however the geographical term Alföld have more sense. In spite of the the geographical context in which we mentioned the Alföld if the area is restricted to the national boundaries (or only to the part of the Alföld) the most appropriate way should be to use with the country's context i.e., Serbian segment of the Alföld or Romanian and Hungarian segments of the Alföld.

The Drava Plain segment of the Drava Plain is slightly different than it defined by Cholnoky [5] and Bulla [13] it seems the delineation near Barcs was arbitrary and the quality or information from relief and slope angles cannot serve such as reliable field data. However, the differences are not significantly big also can interpret those changes as the last century changes. We simply cannot ignore the recent (last century) changes due to natural processes and anthropogenic impacts in the Drava Plain. The geology shows that the Alföld in the Drava valley is westwards of the to the Mid-Hungarian line (for the description of the Mid-Hungarian line see i.e., Csontos \& Nagymarossy, [30] and references therein). 


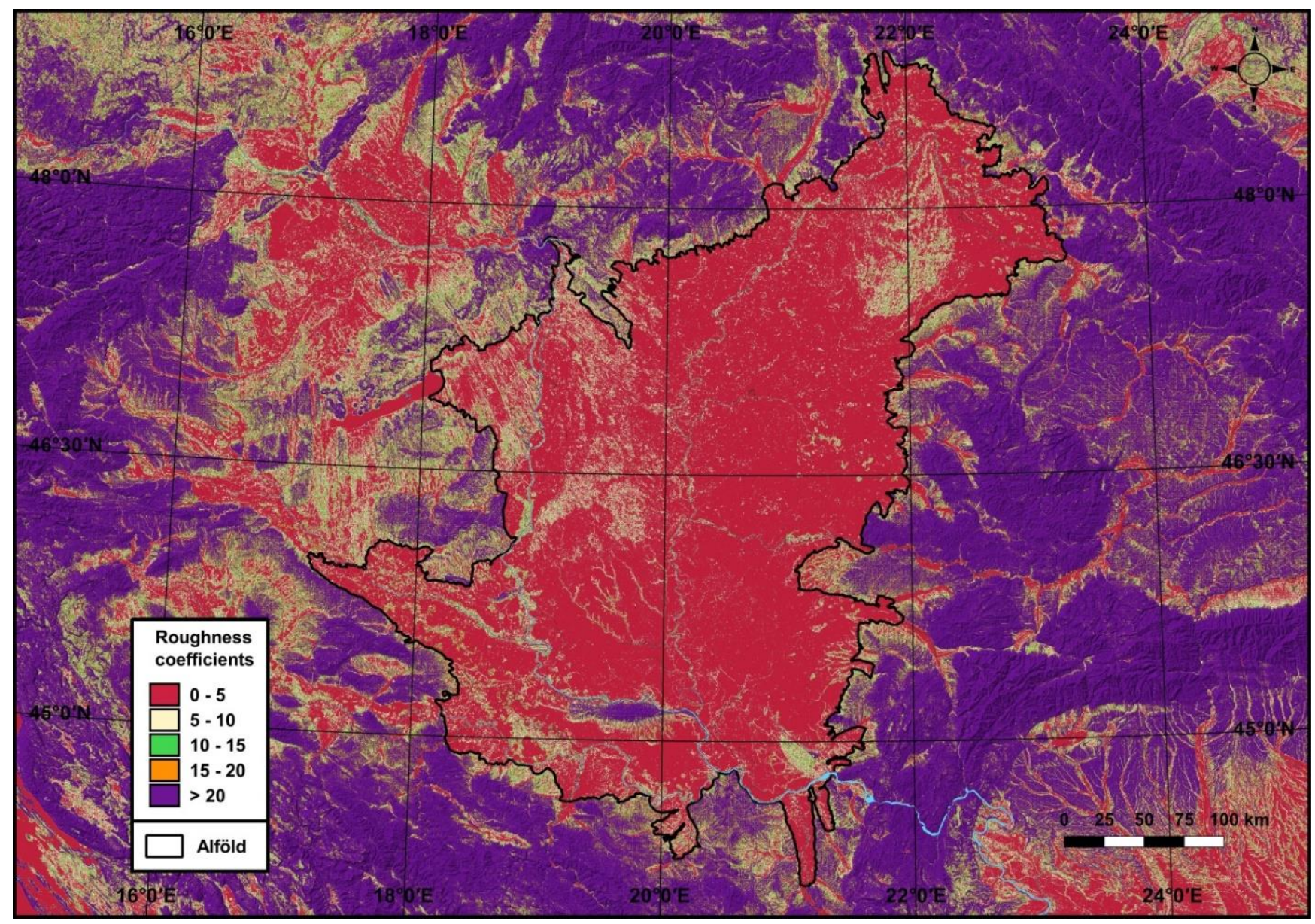

Fig. 2. The delineation of the Alföld based on roughness classification classes with QGIS software. The Alföld boundary shown with black line.

The Southern boundary was described by Bulla [13]. In the case of the Sava valley as the results confirmed by Gaudenyi \& Mihajlović [6] and suggested and written by Bulla [13]. In the case of the Drava Plain the SW line was the Brod Gate in the Sava Plain. It confirms the Lower Sava Sava Plain is a part of the Alföld (e.g., Gaudenyi \& Mihajlović, [6]; Ćalić et al. [25], [26]).

The area of the Alföld southwards from the Sava and the Danube was previously defined by Ćalić et al. [25], [26]) and this study also shows that I the studies of Bulla [13], Kocsis [2], Gaudenyi \& Mihajlović [6] got nearly the same results. Small changes were due to different resolution and scales used for the analysis as well as some (dis)advantages of methods/tools used for the land surface analysis.

The QGIS tool "Roughness" was tested for the Western Balkan countries and Central Europe (similar as in the papers of Gaudenyi \& Mihajlović [6]-[8]). The DEM resolution $100 \times 100 \mathrm{~m}$ shows similar results as used in the paper of Ćalić et al. [25], [36] which based on the subsequent calculations and analyses were by using the raster-based GIS software Idrisi Andes. In that case the SRTM was resampled from $90 \times 90 \mathrm{~m}$ grid cells to $200 \times 200 \mathrm{~m}$ grid cells. The $5 \times 5$ cells were gathered into a moving window for calculation of average elevation within a window. In our case when have to make a further generalization. The surface roughness coefficients in the also shown when the coefficient lower than 5 indicated the plain relief (same as coefficients as in Ćalić et al. [25], [26]). However nearly same results got with more simplified method by using QGIS "Roughness" tool. The control checking was done applying the results in the sets of maps published by Gábris et al. [23], Csorba et al. [24] and Ćalić et al. [25], [26]. Although that different methodology was used the results were similar (nearly the same) which confirms that combined several methods of relief analysis when the authors are familiar with the methodology got proper interpretation and the results are comparable. In our case seems that the delineation of the southern boundary is quite clearly defined (Fig. 3).

\section{CONCLUSIONS}

The authors of this study justified to appliy the use of the geographical name Alföld as the proposal of the Alföld Commission of the Hungarian Geographical Society for one of the gratest physico-geographic macroregion / landscape unit of the Carpathian Basin [5]. The frequently used name "Great Hungarian Plain" should be abandoned. If the segment of the Alföld is restricted to the national boundaries it can be used with the prefix which pointed to which country, it belongs (i.e., in case of Hungary it should mention as: the Hungarian segment / part of the Alföld).

The southern boundary of the Alföld is well defined (Fig. 2 and 3). The results of this study in case of the Drava Plain segment of the Alföld, well defined in this study and nearly the same as in Gábris et al. [23]. The Lower Sava Plain is a segment of the Alföld and confirmed the results of the studies of Cholnoky [5], Bulla [30], Gábris et al. [23] as well as Gaudenyi \& Mihajlović [6]. The south boundary of the Alföld in case of the Serbian segment of the Alföld confirms the earlier results of Ćalić et al. [25], [26]. 


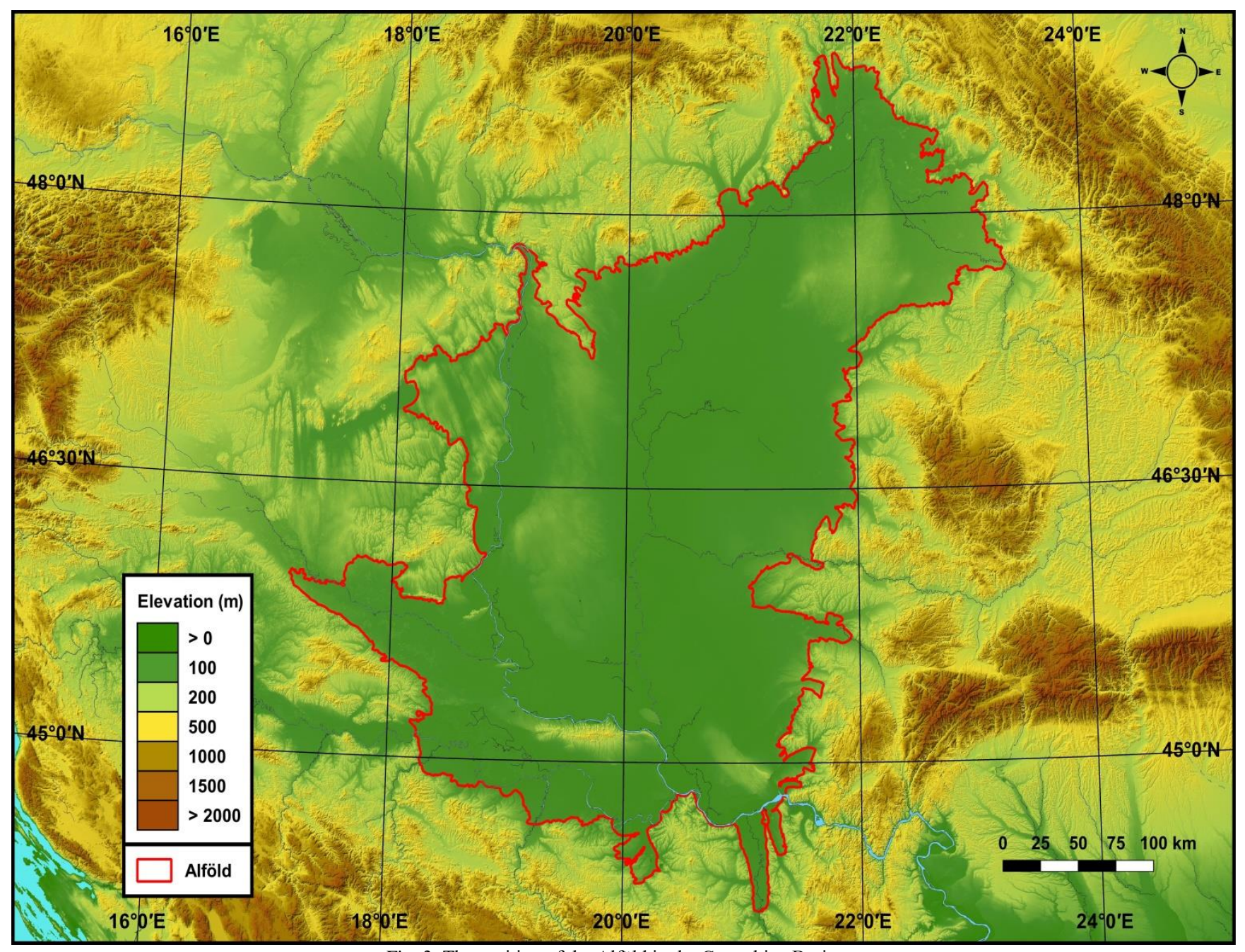

Fig. 3. The position of the Alföld in the Carpathian Basin.

\section{ACKNOWLEDGMENT}

The authors are grateful to Árpád Magyar, librarian of the Geographical Institute at Research Centre for Astronomy and Earth Sciences in Budapest (Hungary) for supplying the requested PDFs from their holdings.

\section{FUNDING}

The investigations of Tivadar Gaudenyi were supported by the Bolyai János Research Grant of the Hungarian Academy of Sciences.

\section{REFERENCES}

[1] Kocsis K, Schweizer F, Eds. Hungary in Maps. Budapest: Geographical Research Institute, Hungarian Academy of Sciences; 2009.

[2] Kocsis K. Ed. National Atlas of Hungary: Vol. 2. Natural Environment. Budapest: Hungarian Academy of Sciences, Research Centre for Astronomy and Earth Sciences, Geographical Institute; 2018.

[3] Lóczy D. Geomorphological Regions. In: Lóczy D. Ed. Landscapes and Landforms of Hungary. World Geomorphological Landscapes Series. Springer international Publishing Switzerland; 2015, pp. 39-46.

[4] Mezősi G. 7 Physical Geography of the Great Hungarian Plain. In: The Physical of Hungary. Geography of the Physical Environment Series. Mezősi G. Ed. Springer International Publishing Switzerland; 2017. pp. 195-230.

[5] Cholnoky J. Az Alföld felszíne. Földrajzi Közlemények, 1910;38(10):413-414. Hungarian.
[6] Gaudenyi T, Mihajlović M. The Sava Plain: denomination, definition and subdivision. European Journal of Environment and Earth Sciences, 2022, 3 (1): 54-60.

[7] Gaudenyi T, Mihajlović M. Pan Plain. EJ-GEO forthcoming 2022.

[8] Gaudenyi T, Mihajlović M. Carp. Basin. EJ-GEO forthcoming 2022.

[9] QGIS $2.8 \quad$ User $\quad$ Guide. Internet (http//docs.qgis.org/2.8/en/user_manual/processing_als/gdalogr/gdal_ analysis/roughness-html derived on March 1st, 2020)

[10] Cholnoky J. Az Alföld felszíne. Erdészeti Lapok, 1924; 63 (3): 50-60. Hungarian.

[11] Cholnoky J. Az Alföld felszíne. Erdészeti Lapok, 1924; 63(4), 65-69. Hungarian.

[12] Cholnoky J. Alföldünk morfológiai problémái. Földrajzi Közlemények, 1928; 66 (5-6), 87-93.

[13] Bulla B. Az Alföld. Kincsestár: A Magyar Szemle Társaság Kis Könyvtára vol. 116. Budapest: Magyar Szemle Társaság; 1940. Hungarian.

[14] Bulla B. III. A Kárpát-medence tájai: 1. Az Alföld. In: Bulla B, Mendöl T. Eds. A Kárpát-medence földrajza. Nevelök Könyvtára 2. Budapest: Országos Köznevelési Tanács, 1947. pp. 196-225. Hungarian.

[15] Pécsi M. Geomorphological Regions of Hungary. Studies Geography in Hungary. Budapest: Geographical Research Institute - Hungarian Academy of Sciences; 1970. Hungarian.

[16] Dövényi Z. Ed. A Kárpát-medence földrajza. Budapest: Akadémiai Kiadó; 2012. Hungarian.

[17] Lóczy D, Kertész Á, Lóki J, Kiss T, Rózsa P, Sipos Gy, Sütő L, Szabó L, Veress M. Chapter 9: Recent Landform Evolution in Hungary. In: Recent Landform Evolution: The Carpatho-Balkan-Dinaric Region. Springer Geography Series. Lóczy D, Stankoviansky M, Kotarba M. Eds. Springer Science+Business Media B.V.: 2012. pp. 205-215

[18] Szabó J. A magyar Alföld alakulása földtani tekintetben. A Magyar Tudományos Akadémia Évkönyve vol. 10. Pest: Hungarain Academy of Sciences; 1860. Hungarian.

[19] Hunfalvy J. Egyetemes földrajz különös tekintettel a néprajzi viszonyokra. A Magyar Birodalom Földrajza II. Budapest. Atheneum Társulat kiadása, 1886. Hungarian. 
[20] Hanusz I. A nagy Magyar Alföld földrajzi jellemképekben. Kecskemét: Metzger Béla kiadása; 1895. Hungarian.

[21] Czirbusz G. Balbi Adorján Egyetemes földrajza a művelt közönség számára: Európa Az Alpok és a Kárpátok Hegyvidéke. Vol. 5 (1). Történeti Nép-es Földrajzi Könyvtár 67. Nagybecskerek: Kiadja Szabó Ferenc; 1899. Hungarian.

[22] Fodor, F. (2006). A magyar földrajztudomány története [The history of the Hungarian geography]. Hungarian Academy of Sciences, Research Centre for Astronomy and Earth Sciences, Geographical Institute Budapest.

[23] Gábris Gy, Pécsi, M, Telbisz T. IV. Relief. In: National Atlas of Hungary: Vol. 2. Natural Environment, Kocsis K. Ed. Budapest: Hungarian Academy of Sciences, Research Centre for Astrono my and Earth Sciences, Geographical Institute; 2018. pp. 42-57.

[24] Csorba P, Bartos-Elekes Zs, Bata T, Bede-Fazekas Á, Czúcz B, Csima P, Csüllög G, Fodor N, Frisnyák S, Horváth G, Illés G, Kiss G, Kocsis K, Kollányi L, Konkoly-Gyúró É, Lepesi N, Lóczy D, Malatinszki Á, Mezősi G, Mikesy G, Molnár Zs, Pásztor L, Somodi I, Szegedi S, Szilassi P, Támás L, Tirászi Á, Vasvári M. X. Landscapes. In: National Atlas of Hungary: Vol. 2. Natural Environment. Kocsis K. Ed. Budapest: Hungarian Academy of Sciences, Research Centre for Astronomy and Earth Sciences, Geographical Institute; 2018. pp. 112129.

[25] Ćalić J, Milošević, MV, Gaudenyi T, Štrbac D, Milivojević M. Pannonian Plain as a morphostrucural unit of Serbia. Bulletin of the Serbian Geographical Society, 2012; 92 (1): 47-69.

[26] Ćalić J, Gaudenyi T, Milošević MV, Strbac D, Milivojević M. Geomorphological method for delineation of plains - case study of the south-eastern (Serbian) segment of Pannonain Plain. Carpathian Journal of Earth and Environmental Sciences, 2012; 7 (2): 239-248.

[27] Trunkó L. Ed. Ungarn: Bergland um Budapest, Balaton-Oberland, Südbakony. Sammlung geologischer Führer vol. 91. Berlin - Stuttgart: Gebruder Borntraeger; 2000. German.

[28] von Raumer K. Lehrbuch der allgemeinen Geographie. Leipzig: F.U. Brodhaus; 1848. German.

[29] Wolf H. Geologisch-geographische Skizze der niederungarische Ebene. Jahrbuch der K. k. Geologische Reich-Anstalt, vol 17: 1867. German.

[30] Csontos L. Nagymarossy A. The Mid-Hungarian line: a zone of repeated tectonic inversion. Tectonophysics, 1998; 297: 51-71.

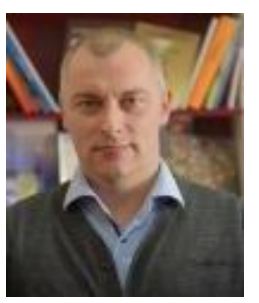

Tivadar Gaudenyi was born in 1975 in Novi Sad (Serbia). He got $\mathrm{PhD}$ of Geographical Sciences (2010) at Faculty of Sciences, University of Novi Sad. Major field of study was physical geography. During studies attended Mr Gaudenyi fellowships at Department of Geology and Paleontology University of Szeged (Hungary), Geological Institute of Hungary (Budapest, Hungary), Department of Quaternary Paleontology, University of Vienna (Austria), Department of Geography, University of Bayreuth (Germany), EM-MIC Lab, University of Bergen (Norway, short courses at RHUL and UCL (London, UK) and University of Oxford (UK).

Research focus defined as: Quaternary environments reconstructions of Central- and SE Europe, Quaternary geology, Quaternary stratigraphy, Quaternary malacology and geomorphology.

Mr Gaudenyi has been employed since 2010 at Geographical Institute "Jovan Cvijic" of the Serbian Academy of Sciences and Arts at the Department of Physical Geography. Mr Gaudenyi has an active role in the Serbian Geological Society and the Serbian Society of Geomorphologists.

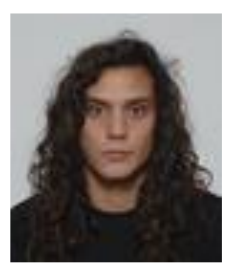

Milan Mihajlović was born in 1994 in Sremska Mitrovica (Serbia). Mr Mihajlović got BSc in Geography at Faculty of Geography, University of Belgrade in 2018 and MSc at Faculty of Forestry, University of Belgrade, Department of Ecological Engineering for Soil and Water Resources Protection in 2019 .

Mr Mihajlović research focuses are studies in physical for analysis and mapping. geography and practical application of GIS software 